\author{
Parimal Chandra BISWAS ${ }^{1}$ \\ Dilip Kumar CHAKRABORTY²
}

\title{
A STUDY OF INDUSTRIAL RELATIONS IN MANUFACTURING INDUSTRIES IN THE ROYAL KINGDOM OF BHUTAN
}

\begin{abstract}
Manufacturing Industries form the backbone of a developing economy like Bhutan. They are one of the most important factors of socio-economic development of the country and an important provider of employment. They contribute 42\% of GDP (2017-2018 Annual Report of Royal Monetary Authority of Bhutan) with around 11 percent of Bhutan's workforce. Bhutan's overall development philosophy is based on the concept of Gross National Happiness (GNH), which challenges the conventional concept of GDP for measuring the progress of the country. Instead it considers the psychological and social wellbeing of the citizens and the need to balance between economic growth and social development.

Industrial Relations in manufacturing industries in Bhutan simultaneously contribute to development of GDP and GNH. Industrial Relations directly reflect Bhutan's national culture, socio-economic development, political-administration, newly developed democracy, corporate culture and integration of Bhutan into global economic process. However, the literature is silent on the study of Industrial Relations (IR) practices in the Bhutanese manufacturing industries. Thus, the researchers' interest is in taking up a study on this vital topic for the economy of Bhutan.
\end{abstract}

Keywords: Industrial Relations, Labour Laws, Organizational Culture, Employee Satisfaction, Gross National happiness.

\section{INTRODUCTION}

We all are witnesses of social and industrial unrests in neighboring countries, like India, Bangladesh, Nepal and in other countries in South East Asia. But something holds together people of this small country and something drives them to be happy with life's minimum in Bhutan. We are familiar with the great teaching of Buddha on life that life is a series of sufferings and problems. Bhutan is a Buddhist country with rooted ancient culture but it has an optimistic outlook concerning life. The country ranks one of the highest peaceful and

${ }^{1}$ Parimal Chandra Biswas, Ph.D., Professor, School of Management, Adamas University, Kolkata, India; e-mail: parimalchandrabiswas@adamasuniversity.ac.in (corresponding author). ORCID: 0000-0002-3377-1878.

${ }^{2}$ Dilip Kumar Chakraborty, Ph.D. Research Scholar, School of Management, Adamas University, Kolkata, India; e-mail: kumardilip1652@gmail.com. ORCID: 0000-0002-0114-6111. 
happiest countries in the world and boldly preaches Gross National Happiness to the world as a national goal. It is encouraging to learn how labour class copes with life challenges in order to keep and support harmony with one another and pursues happiness in life in this wonderful country.

\section{BHUTAN CONTEXT}

The Royal Kingdom of Bhutan is a small country with monarchy ruling system, located between two large and powerful nations, China and India. Bhutan has a total land area of 38,394 square kilometers, roughly about the same size as Switzerland. It is a mountainous country, where only three per cent of the land is cultivatable, about four per cent of the land is pasture land, and 70 per cent is covered with forest. The total population of Bhutan is recorded 768577 in 2016. Population Density (Person per sq. $\mathrm{km}$ ) is 20 as per office record in the year of 2016. Buddhism continues to play a central role in shaping social values and culture in Bhutan. The majority of the population are Buddhists whilst people in the southern part of Bhutan are mostly Hindus.

Bhutan is one of the few countries in Asia which was never colonised by the British Empire. In terms of gender equality, in fact in terms of property rights women have more property rights in some parts of Bhutan than the men. For instance, in the western part of Bhutan, daughters inherit more land than sons. Bhutan is a high ranking peaceful and happy country in the world.

\section{RESEARCH OBJECTIVES}

Though IR practices comprise of multiple issues, the researchers have put following major objectives in the study, which contribute to development of GDP and GNH of Bhutan.

1. To study IR practices in manufacturing industries in Bhutan.

2. To do comparative analysis of IR practices in manufacturing industries of different ownership in Bhutan.

\section{RESEARCH DESIGN AND FINDINGS}

The researchers have studied Industrial Relations (IR) practices in nine manufacturing industries of different ownerships in Bhutan using one set of questionnaires. Total respondents were 294 people including managers and employees. The questionnaires were framed and structured using 5 Point Likert Scale. For comparative analysis only three manufacturing industries of different ownership have been chosen for the study.

For each of the above sections, the common 5 point rating scale goes like this:

Strongly Disagree $\quad$ - indicated by 1

Disagree $\quad$ - indicated by 2

Neither Agree nor Disagree - indicated by 3

Agree $\quad$ - indicated by 4

Strongly Agree $\quad$ - indicated by 5 
Table 1. Questionnaire for studying Industrial Relations (IR) Practices

\begin{tabular}{|l|l|}
\hline Attributes & \multicolumn{1}{c|}{ Questions } \\
\hline IR1 & $\begin{array}{l}\text { Worker/employee grievances in the company are handled by the authority concerned } \\
\text { with due care. }\end{array}$ \\
\hline IR2 & HR/IR executives are delegated to look after the employee welfare administration. \\
\hline IR3 & $\begin{array}{l}\text { Collective bargaining process is the method to safeguard, protect and improve the } \\
\text { employer and employee relationship in the company. }\end{array}$ \\
\hline IR4 & $\begin{array}{l}\text { Management is always active for communicating and discussing day to day } \\
\text { operational problems/issues with the trade union or workers' association/workers' } \\
\text { representatives. }\end{array}$ \\
\hline IR5 & $\begin{array}{l}\text { Management of the company always promotes workers' participation in decision } \\
\text { making process of the organization. }\end{array}$ \\
\hline IR6 & $\begin{array}{l}\text { Management believes in Win-Win situation in any negotiation/collective bargaining } \\
\text { process. }\end{array}$ \\
\hline IR7 & $\begin{array}{l}\text { Trade Union/workers' associations/local workers' representatives encourage and } \\
\text { cooperate to reach in 'Win-Win' situation in any negotiation/collective bargaining } \\
\text { process. }\end{array}$ \\
\hline IR8 & $\begin{array}{l}\text { Management representatives especially HR/IR executives are very active to } \\
\text { participate in any events/occasions/rituals organized by the workers/employees } \\
\text { of the company. }\end{array}$ \\
\hline IR9 & $\begin{array}{l}\text { Both the management and workers representatives /trade union always prefer } \\
\text { amicable settlement of any company disputes/conflicts without conciliation } \\
\text { proceedings/adjudication by labor tribunal. }\end{array}$ \\
\hline IR10 & \begin{tabular}{l} 
IR practices are influenced by GNH culture of Bhutan. \\
\hline
\end{tabular} \\
\hline
\end{tabular}

\section{Frequency distributions for Industrial Relations (IR) practices in the industries}

Table 2. Frequency distributions of Industrial Relations (IR) Practices (\%)

\begin{tabular}{|l|c|c|c|c|c|}
\hline Attributes & $\mathbf{1}$ & $\mathbf{2}$ & $\mathbf{3}$ & $\mathbf{4}$ & $\mathbf{5}$ \\
\hline IR1 & 5 & 7 & 15 & 53 & 20 \\
\hline IR2 & 4 & 10 & 20 & 50 & 16 \\
\hline IR3 & 3 & 7 & 28 & 49 & 13 \\
\hline IR4 & 6 & 11 & 23 & 46 & 14 \\
\hline IR5 & 11 & 25 & 21 & 36 & 7 \\
\hline IR6 & 4 & 10 & 26 & 37 & 23 \\
\hline IR7 & 10 & 21 & 31 & 32 & 6 \\
\hline IR8 & 6 & 10 & 22 & 40 & 22 \\
\hline IR9 & 4 & 6 & 32 & 43 & 15 \\
\hline IR10 & 5 & 7 & 23 & 35 & 30 \\
\hline
\end{tabular}

The maximum number of respondents agree that worker/employee grievances in the company are handled by the authority concerned with due care, which is supported by $53 \%$ 
respondents. The minimum number of respondents agree that Trade Union/workers' associations/local workers' representatives encourage and cooperate to reach in 'Win-Win' situation in any negotiation/collective bargaining process, which is supported by $32 \%$ respondents.

An analysis of IR practices by main domains

Table 3. Survey of Industrial Relations Practices by main domains

\begin{tabular}{|c|c|c|c|c|}
\hline $\begin{array}{l}\text { Main } \\
\text { Domains }\end{array}$ & Questions & $\begin{array}{c}\text { Total } \\
\text { Agree } \\
\%\end{array}$ & $\begin{array}{c}\text { Total } \\
\text { Disagree } \\
\%\end{array}$ & $\underset{\%}{\text { Neutral }}$ \\
\hline \multirow[t]{3}{*}{$\begin{array}{l}\text { Collective } \\
\text { Bargaining }\end{array}$} & $\begin{array}{l}\text { IR3 Collective bargaining process is the } \\
\text { method to safeguard, protect and improve the } \\
\text { employer and employee relationship in the } \\
\text { company. }\end{array}$ & 62 & 10 & 28 \\
\hline & $\begin{array}{l}\text { IR6 Management believes in Win-Win } \\
\text { situation in any negotiation/collective bar- } \\
\text { gaining process. }\end{array}$ & 60 & 17 & 23 \\
\hline & $\begin{array}{l}\text { IR7 Trade Union/workers' associations/local } \\
\text { workers' representatives encourage and } \\
\text { cooperate to reach in 'Win-Win' situation in } \\
\text { any negotiation/collective bargaining pro- } \\
\text { cess. }\end{array}$ & 38 & 31 & 31 \\
\hline \multirow[t]{2}{*}{$\begin{array}{l}\text { Grievance } \\
\text { Handling }\end{array}$} & $\begin{array}{l}\text { IR1 Worker/employee grievances in the } \\
\text { company are handled by the authority } \\
\text { concerned with due care. }\end{array}$ & 73 & 11 & 16 \\
\hline & $\begin{array}{l}\text { IR9 Both the management and workers } \\
\text { representatives /trade union always prefer } \\
\text { amicable settlement of any company } \\
\text { disputes/conflicts without conciliation pro- } \\
\text { ceedings/adjudication by labor tribunal. }\end{array}$ & 58 & 10 & 32 \\
\hline \multirow[t]{5}{*}{$\begin{array}{l}\text { Relationship } \\
\text { Building }\end{array}$} & $\begin{array}{l}\text { IR2 HR/IR executives are delegated to look } \\
\text { after the employee welfare administration. }\end{array}$ & 67 & 13 & 20 \\
\hline & $\begin{array}{l}\text { IR4 Management is always active for } \\
\text { communicating and discussing day to day } \\
\text { operational problems/issues with the trade } \\
\text { union or workers' association/workers' } \\
\text { representatives. }\end{array}$ & 60 & 17 & 23 \\
\hline & $\begin{array}{l}\text { IR5 Management of the company always } \\
\text { promotes workers' participation in decision } \\
\text { making process of the organization. }\end{array}$ & 43 & 36 & 21 \\
\hline & $\begin{array}{l}\text { IR8 Management representatives especially } \\
\text { HR/IR executives are very active to } \\
\text { participate in any events/occasions/rituals } \\
\text { organized by the workers/employees of the } \\
\text { company. }\end{array}$ & 62 & 16 & 22 \\
\hline & $\begin{array}{l}\text { IR10 IR practices are influenced by GNH } \\
\text { culture of Bhutan. }\end{array}$ & 65 & 12 & 23 \\
\hline
\end{tabular}


Collective Bargaining process in manufacturing industries in Bhutan is in the beginning stage of development. 38\% respondents believe that Trade Union/workers' associations/local workers' representatives encourage and cooperate to reach in 'Win-Win' situation in any negotiation/collective bargaining process. $73 \%$ agree that worker/employee grievances in the company are handled by the authority concerned with due care. Only $43 \%$ respondents agree that Management of the company always promotes workers' participation in decision making process of the organization. But $65 \%$ believe that IR practices are influenced by GNH culture of Bhutan.

\section{A comparative analysis of IR practices in industries of different ownership}

Table 4. Survey of Industrial Relations in manufacturing industries of different ownership

\begin{tabular}{|c|c|c|c|c|c|c|c|c|c|c|}
\hline \multirow{2}{*}{$\begin{array}{c}\text { Main } \\
\text { Domains }\end{array}$} & \multirow{2}{*}{$\begin{array}{l}\text { Ques- } \\
\text { tions }\end{array}$} & \multicolumn{3}{|c|}{$\begin{array}{c}\text { Government Company } \\
\text { BBPL }\end{array}$} & \multicolumn{3}{|c|}{$\begin{array}{c}\text { Private Company } \\
\text { Lhaki Steel }\end{array}$} & \multicolumn{3}{|c|}{$\begin{array}{c}\text { Joint Venture } \\
\text { BFAL }\end{array}$} \\
\hline & & $\begin{array}{l}\text { TA } \\
(\%)\end{array}$ & $\begin{array}{l}\mathrm{TD} \\
(\%)\end{array}$ & $\begin{array}{c}\mathrm{N} \\
(\%)\end{array}$ & $\begin{array}{l}\text { TA } \\
(\%)\end{array}$ & $\begin{array}{l}\mathrm{TD} \\
(\%)\end{array}$ & $\begin{array}{l}\mathrm{N} \\
(\%)\end{array}$ & $\begin{array}{l}\text { TA } \\
(\%)\end{array}$ & $\begin{array}{l}\mathrm{TD} \\
(\%)\end{array}$ & $\begin{array}{c}\mathrm{N} \\
(\%)\end{array}$ \\
\hline \multirow{3}{*}{$\begin{array}{l}\text { Collective } \\
\text { Bargaining }\end{array}$} & IR 3 & 50 & 7 & 43 & 63 & 0 & 37 & 45 & 17 & 38 \\
\hline & IR 6 & 37 & 17 & 46 & 41 & 4 & 45 & 55 & 17 & 28 \\
\hline & IR 7 & 37 & 10 & 53 & 41 & 10 & 49 & 55 & 13 & 27 \\
\hline \multirow{2}{*}{$\begin{array}{l}\text { Grievance } \\
\text { Handling }\end{array}$} & IR 1 & 77 & 10 & 13 & 90 & 0 & 10 & 58 & 12 & 30 \\
\hline & IR 9 & 60 & 0 & 40 & 34 & 10 & 56 & 50 & 12 & 38 \\
\hline \multirow{5}{*}{$\begin{array}{l}\text { Relation- } \\
\text { ship } \\
\text { Building }\end{array}$} & IR 2 & 57 & 10 & 33 & 72 & 0 & 28 & 45 & 20 & 35 \\
\hline & IR 4 & 33 & 17 & 50 & 72 & 24 & 4 & 43 & 20 & 37 \\
\hline & IR 5 & 67 & 0 & 33 & 63 & 7 & 31 & 55 & 22 & 23 \\
\hline & IR 8 & 50 & 7 & 43 & 45 & 10 & 45 & 53 & 22 & 25 \\
\hline & IR 10 & 73 & 10 & 17 & 35 & 10 & 55 & 55 & 20 & 25 \\
\hline
\end{tabular}

Note: BBPL: Bhutan Boards Products Limited, Govt Owned Company

Lhaki Steel Private Limited Company

BFAL: Bhutan Ferro Alloys Limited, Joint Venture Company

TA: Total Agreed, TD: Total Disagreed, N: Neutral

Collective Bargaining process in all industries is not understood correctly. $41 \%$ respondents believe that Trade Union/Workers' Associations/local workers' representatives encourage and cooperate to reach in 'Win-Win' situation in any negotiation/collective bargaining process (IR6) in the Private company Lhaki Steel, 37\% respondents in the government owned company BBPL and 55\% respondents in the joint venture BFAL.

Grievance handling is better performed in the private company than in both of the government owned company and the Joint venture. 90\% respondents agree that worker/employee grievances in the company are handled by the authority concerned with due care (IR1) in Lhaki Steel, 77\% respondents in BBPL and 58\% respondents in the joint venture BFAL.

Only $63 \%$ respondents agree that Management of the company always promotes workers' participation in decision making process of the organization (IR5) in the private company Lhaki Steel, 67\% respondents in the government owned company BBPL and 55\% respondents in the joint venture BFAL. 
Only 35\% respondents believe that IR practices are influenced by GNH culture of Bhutan (IR10) in in the private company Lhaki Steel, 73\% respondents in the government owned company BBPL and 55\% respondents in the joint venture BFAL.

\section{CONCLUSIONS}

The study concludes that IR practices under new democracy in manufacturing industries are developing but without huge public and social conflicts and unrests, which are common in other neighbouring countries. Due to good human relations among people, rooted in their national culture employees cope with life challenges more softly in order to keep and support harmony with one another and pursue happiness in life in this wonderful country. With minimum level of salaries, wages, moderate working conditions, less economic and social benefits they are content with their jobs and management people. The research proves that Bhutan is a peace seeking country and it pursues successfully Gross National Happiness as their national goal.

\section{REFERENCES}

Gallenkamp, M. (2011). The history of institutional change in the kingdom of Bhutan: A tale of vision, resolve, and power. "Heidelberg Papers in South Asian and Comparative Politics", Vol. 61.

Turner, M., and Tshering, J. (2014), Is Democracy Being Consolidated in Bhutan? "Asian Poltics \& Policy Journal", Vol. 6(3).

Tshering Yangden (2009), Gender, Culture and Development: In the Paradigm of Gross National Happiness in Bhutan, School of Social and Political Sciences, University of Canterbury, Christchurch, New Zealand.

Ugyen Tshewang (2015), Civil Service HRM Reforms in a new Democracy: The Case of Bhutan, School of Management, QUT School of Business, Queensland University of Technology, Brisbane, Queensland, Australia.

DOI: $10.7862 /$ rz.2020.mmr.1

The text was submitted to the editorial office: March 2020.

The text was accepted for publication: March 2020. 